\title{
Assessment of Impact of 'Drug Price Control Order 2013' For Essential Medicines in India
}

\author{
Authors \\ Dr Sonali Ramakant More ${ }^{1}$, Dr Balasaheb Baburao Ghongane ${ }^{2}$ \\ ${ }^{1}$ Assistant Professor, ${ }^{2}$ Professor and Head, \\ Department of Pharmacology, B.J. Government Medical College and Sassoon General Hospital \\ Pune - 411001. Maharashtra, India \\ Corresponding Author \\ Dr Sonali Ramakant More \\ Email-sonamore11@gmail.com, M- +91:9619677292
}

\begin{abstract}
Drug Price Control Order (DPCO) 2013 was issued by Central Government to make available essential medicines at reasonable cost. Present study was planned in year 2013 to estimate perceived and economic impact. It was cross sectional, observational study. Questionnaires were filled by each 60 clinicians, pharmacists, patients, postgraduate medical students, interns. Maximum Retail Prices (MRPs) of 348 essential medicines were searched in CIMS printed hand-books in last quarter of 2012 and each quarter of 2013. MRPs of 287 essential medicines were available. Percentage change in MRPs was calculated. The awareness and knowledge of DPCO 2013 was highest amongst pharmacists (100\%) followed by clinicians (80\%), postgraduate students (68.33\%), interns (58.33\%) and least in patients (21.68\%). $83 \%$ pharmacists, $74 \%$ clinicians, $58 \%$ post-graduate students, $35 \%$ interns, $22 \%$ patients were responded that beneficiary entity after DPCO 2013 implementation is patient. $88.33 \%$ pharmacists opined that essential medicines e.g. azithromycin, metoprolol, diclofenac were unavailable. Out of 287, MRPs of 250 essential medicines were reduced. 2 drugs were showing 75-100\% price reduction and 164 drugs were showing 0 to $24 \%$ reduction. The maximum percentage reduction in MRP was seen for chlorambucil (80.64\%) followed by vitamin A (79.33\%). The awareness and knowledge of DPCO 2013 was insufficient in postgraduate medical students, interns as compared to pharmacists. MRPs were reduced significantly with Chlorambucil, Vitamin A, Famotidine, Bupivacaine, Artesunate etc so as to make them affordable for common man; however there was non-availability of commonly used essential medicines after DPCO 2013 implementation.
\end{abstract}

Keywords- Essential medicines, Drug Price Control Order 2013, Drug prices, Maximum retail prices, Pharmacoeconomics.

\section{INTRODUCTION}

India is one of the developing countries where substantial proportion of population of country is largely exposed to the drug market whose purchasing power is extremely low. Around $42 \%$ population of this country lives under the National poverty line ${ }^{[1]}$. Drugs are recognized as 'essential commodity' should always be available at a 
reasonable price ${ }^{[2]}$. To fix the maximum retail prices of drug formulations, to restrain the exorbitant profiteering in drug manufacturing and distribution, the Drug price control order (DPCO) has been introduced by the National Pharmaceutical Pricing Authority (NPPA) in a phased manner ${ }^{[3]}$.

In 1970s Government of India established rules to control drug prices. In 1979, 347 drugs were under the price control, which came down to 166 in 1987 and further reduced to 142. After the Drug Price Control Order (DPCO) 1995, Indian Government had controlled prices of 74 drugs formulations. The new regime has been replaced 18 years old DPCO 1995 and come into effect 45 days from the publishing date ${ }^{[3,4,5]}$. India's Department of Pharmaceuticals on 15th may 2013 published the Drug Price Control Order, 2013, authorizing the NPPA to control prices of drugs under India's National List of Essential Medicines (NLEM) 2011 ${ }^{[6]}$ using new market-based rules. The Ministry of Health \& Family Welfare had approved that if affordable healthcare has to become a reality, all 348 medicines included in the NLEM, 2011 brought within the ambit of price control under the DPCO 2013, considering the fact that a large percentage of our people do not have access to affordable healthcare ${ }^{[4]}$. As per the new DPCO 2013, all strengths and dosages specified in the NLEM 2011 (652 formulations) were brought under price control.

The $20 \%$ retail margin and $10 \%$ wholesale margin earned by Chemists Under DPCO $1995^{[6]}$, has reduced to $13 \%$ retail and $6 \%$ wholesale margin after DPCO 2013 implementation ${ }^{[4]}$. This led to production rate cut up-to 20-30\%. Hence, it has caused disaster to retailers \& manufacturers ${ }^{[7]}$. Due to the DPCO 2013, the stress on MNCs concerning price determination is increased. Prices of many MNCs off patent branded drugs are controlled by $\mathrm{DPCO}^{[8]}$.

DPCO 2013 shifts the ceiling price calculation from a cost based to a market based method. It has been a benefit for common people as the drug price of several life-saving medicines has been reduced but the wholesalers and retailers have faced a great loss as the margin goes down ${ }^{[9]}$.

The available studies or reports ${ }^{[7,9,10]}$ available are having various lacunae like coverage of a limited number of drugs or special group of drugs, lack of clarity regarding their objectives. No study is available regarding interview based perceived impact regarding knowledge and awareness of DPCO 2013 in medical personnel and patients. Hence this study was planned to survey knowledge and awareness regarding DPCO 2013 order amongst medical personnel like clinicians, postgraduate medical students and interns, pharmacists and patients as well as to study economic impact on essential medicines. In this study economic impact was assessed in terms of percentage change in MRPs of essential medicines after implementation of DPCO 2013. An easy way to comply with the Recent Science journal paper formatting requirements is to use this document as a template and simply type your text into it.

\section{MATERIALS AND METHODS \\ Study Design}

It was cross sectional, observational study. This study was conducted in B.J. Government medical college and Sassoon General Hospital in Pune for calendar year 2014. It was conducted after obtaining approval from Ethics committee. The study was approved by institutional ethics committee and carried out according to the Indian Council of Medical Research (ICMR) Guidelines [11] for Biomedical Research in Humans (2006); and in compliance with the International Conference on Harmonisation / Good Clinical Practice (ICH/GCP) Guidelines ${ }^{[12]}$.

\section{Data collection}

Part A - To study interview based perceived impact, questionnaires were prepared for 5 groups namely Clinicians, Post graduate medical students, Interns, Patients and Pharmacists to assess knowledge, awareness and attitude towards DPCO 2013.

I.CLINICIANS and POST-GRADUATE students Questionnaire was distributed to 60 assistant 
professors and 60 post-graduate students working in Medicine, surgery, Obstetrics - Gynaecology, Paediatrics, Ear Nose \& Throat, Ophthalmology, Psychiatry, Skin, Pharmacology, and Orthopaedics in Sassoon General Hospital, Pune while those in Anatomy, Physiology, Biochemistry, Microbiology, Pathology, FMT, PSM, Anaesthesiology were excluded (not involved in prescribing drugs).

II.INTERNS- Questionnaire was given to 60 Interns working in Sassoon General Hospital, Pune for calendar year 2013.

III.PHARMACISTS- Questionnaire was given to the 60 pharmacists working in Sassoon General Hospital, Pune as well as pharmacist running nearby hospital.

IV.PATIENTS- Questionnaire was given to patients coming in general as well as special Out Patient Departments (OPDs).

A) Inclusion criteria

i. Outpatients with age 18 years and above.

ii. Patients attending major OPDs like general medicine, surgery, obstetrics and gynaecology, and Special OPDs in tertiary care hospital.

iii. Patients of either sex.

iv. Those attending OPD in one calendar year from 01.10 .2013 to 31.12 .2013

B) Exclusion criteria

i. Indoor patients.

ii. Patients coming in paediatric OPD, psychiatric OPD.

The feedback data and results obtained from questionnaire were analysed in Microsoft office excel 2010 and represented graphically.

\section{Data collection}

Part B - To study actual economic impact, data was collected in form of MRPs of all 348 essential medicines before and after DPCO 2013 implementation from CIMS (Current Index of Medical Specialties) India ${ }^{[13]}$ printed hand-books. The MRPs were collected from quarters OctoberDecember 2012 (Q1), January - April 2013 (Q2), April - July 2013(Q3), July- October 2013(Q4) and October - December 2013 (Q5). Only those drugs were taken into consideration whose MRPs were quoted in CIMS printed hand-books. The MRPs 287 essential medicines were available in CIMS printed hand-books and MRPs of 61 essential medicines were unavailable.

Inclusion and exclusion criteria for the drugs included in the study as follows...

A) Inclusion criteria -

i. Essential drugs from NLEM 2011.

ii. Drug prices that were quoted in CIMS India printed hand-book.

iii. If drug is available in more than two formulations, only highest strength of formulation was taken into consideration.

iv. If drug was available in more than two dosage forms then preference was given by order Oral > Injectable > Topical

B) Exclusion criteria

i. Non- essential drugs

ii. Fixed drug dose combinations of non essential medicines

iii. Strengths of formulation other than its highest strength if more than two strengths were available of same dosage form.

iv. Essential medicines whose maximum retail prices were not quoted in CIMS India printed hand-book.

Statistical Analysis: Average MRP of particular drug included in NLEM 2011 for particular quarter (X) was calculated as follows-

' $n$ ' = no of manufacturer producing that drug in Indian market

Then $\mathrm{X}$ was calculated by following formula, Maximum value + Minimum value of drug Average $\operatorname{MRP}(\mathrm{X})=$

\section{2}

Averages MRP of particular drug for last quarter of 2012 and each quarter of 2013 was calculated in Microsoft office excel 2010 for 287 essential medicines. Cost per unit ( $\mathrm{mg}$ or $\mathrm{ml}$ ) of that particular drug was calculated by following formula in Microsoft office excel 2010.

Cost per Unit

Average MRP of the drug

$($ Per $\mathrm{mg}$ or $\mathrm{ml}) \quad=$

Total quantity of drug (mg or $\mathrm{ml})$ 


\section{JMSCR Vol||05||Issue||02||Page 18002-18012||February}

The percentage reduction in MRPs during each quarter of 2013 as compared to Oct - Dec 2012 (Q1) was calculated to estimate economic impact of the DPCO2013 on drug prices.

Percentage change in MRP in Q5 (Oct - Dec 2013) as compared to price in $\mathrm{Q} 1=$

Cost per unit value in Q5 - Cost per unit value of Q1

Cost per unit value in $\mathrm{Q} 1$

$* 100$

\section{RESULTS}

\section{Part A}

In the study of interview based perceived impact, all the stakeholders were responded to their respective questionnaire. It was observed that awareness of term drug price control order 2013 was highest amongst pharmacists followed by clinicians and least in patients. It was found that awareness was $100 \%$ for pharmacists, $80 \%$ for clinicians, $68.33 \%$ for post-graduate students, $58.33 \%$ in interns and $21.66 \%$ in patients. [Figure 1]

Figure 1: Awareness of Drug Price Control Order 2013 in Stakeholders namely Pharmacists, Clinicians, Post-graduate medical Students, Interns and Patients.

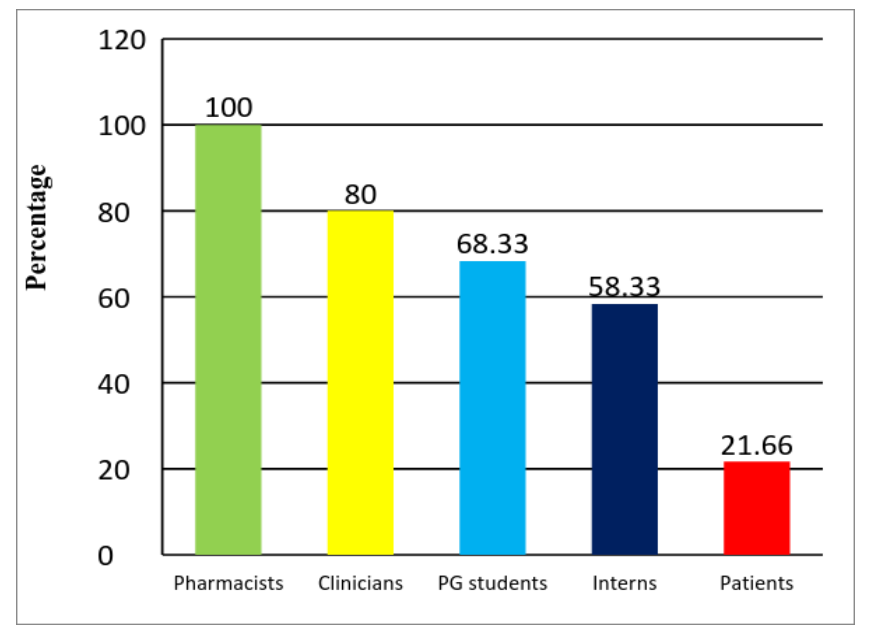

It was found that newspaper was found most common source of information regarding DPCO 2013 followed by internet and least common source was found TV. Amongst all stakeholders, $51.90 \%$ of them replied that newspaper was the common source regarding DPCO 2013 followed by internet (20.25\%), colleagues and friends (16.46\%) and TV $(11.39 \%)$. This question was not allotted to pharmacists. [Figure 2]
Figure 2: Opinion of Stakeholders Regarding Source of Information of DPCO 2013 Order amongst Clinicians, Post-graduate students, Interns and Patients

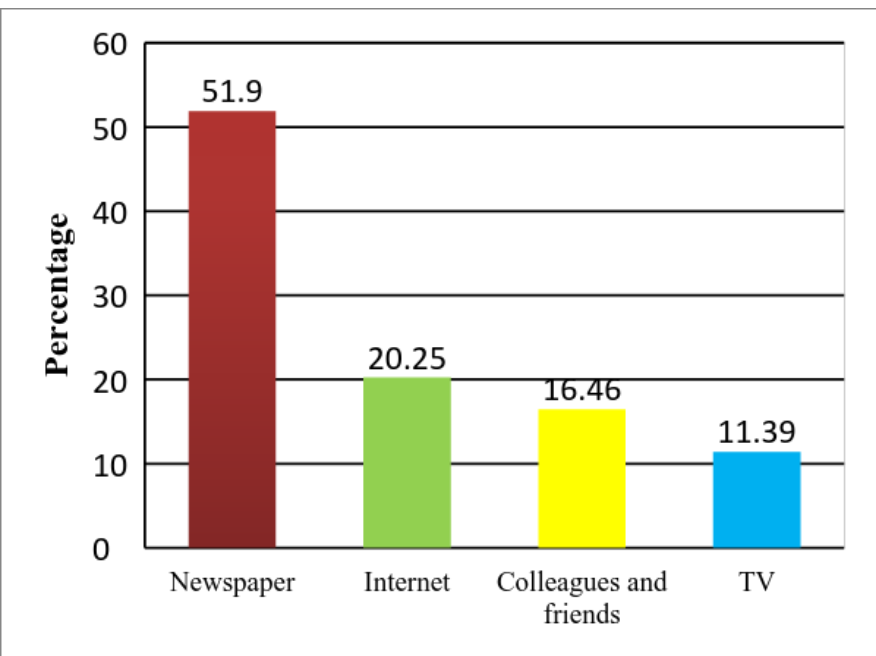

Regarding opinion of stakeholders, $83 \%$ pharmacists $74 \%$ clinicians, $58 \%$ post-graduate students, $35 \%$ interns, and $28 \%$ patients were responded that maximum beneficiary agent after DPCO 2013 implementation is Patient. [Figure 3]

Figure 3- Opinion of Stakeholders - Patient as Maximum Beneficiary Agent after DPCO 2013 Implementation.

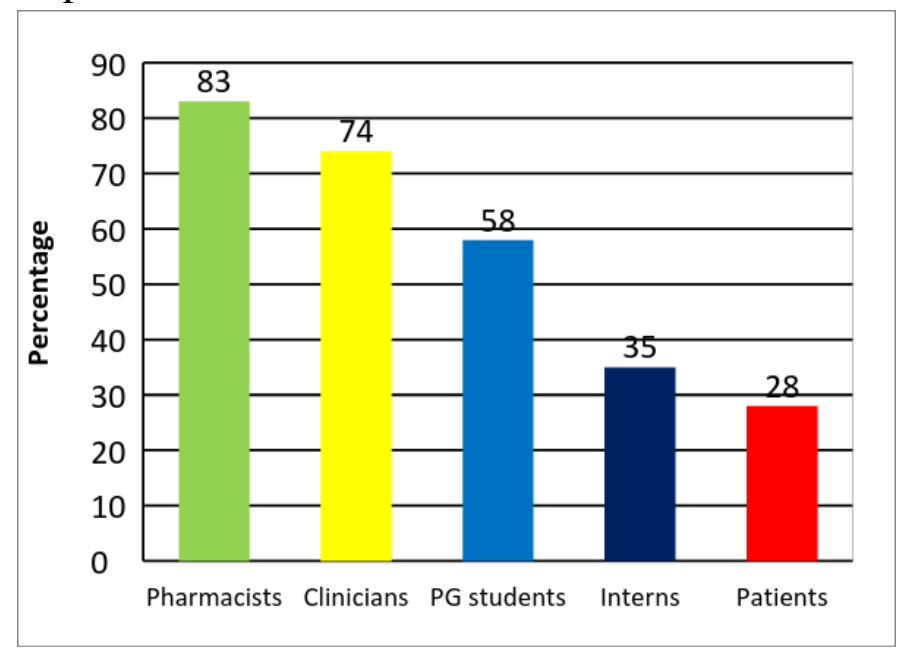

Regarding opinion of stakeholders about availability of essential medicines after DPCO 2013 implementation, $88.33 \%$ pharmacists were responded that some of the medicines were out of stock and only $11.67 \%$ pharmacists were replied that there was no substantial change in accessibility of medicines. 
$28.33 \%$ clinicians were specified that some of the medicines were out of stock while $41.67 \%$ were stated that there was an increase in availability of essential medicines after implementation of DPCO 2013 and $10 \%$ of them were responded that there was no substantial alteration. Major portion i.e. $45 \%$ post-graduate students were in opinion of increase availability of essential medicines while $41.67 \%$ of interns are unaware of DPCO 2013. Similarly, $76.67 \%$ of patients were also unaware of DPCO 2013 order. [Figure 4]

Figure 4: Opinion of Stakeholders Regarding Availability of Essential Medicines after Implementation of DPCO 2013.

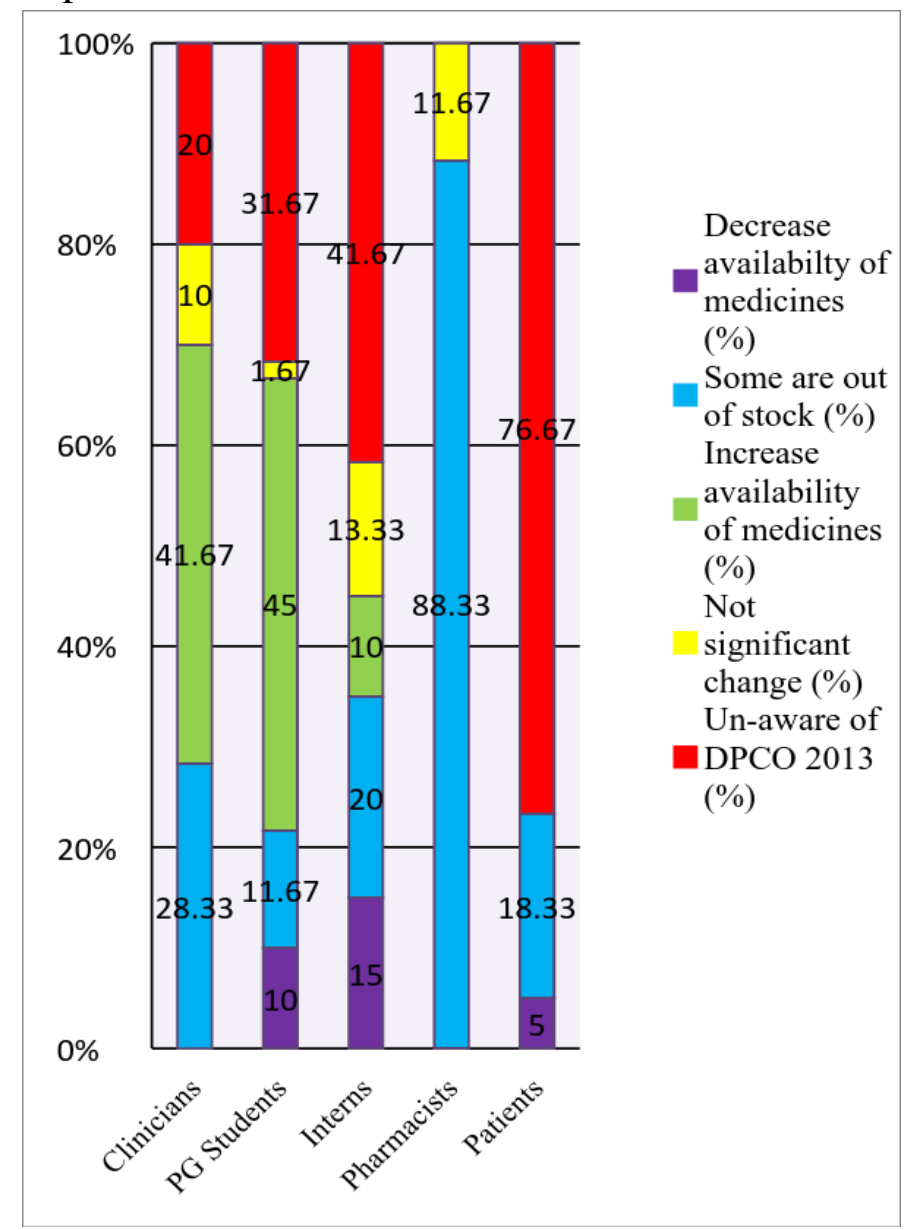

Regarding opinion of stakeholders on pharmacist's profit after DPCO 2013 implementation, 53.33\% pharmacists were responded that decrease in profit and $11.67 \%$ were replied that there was a significant decrease in profit; remaining $28.33 \%$ were specified that there was not a significant change in profit after DPCO 2013 implementation. As per as other stakeholders were concerned, $51.66 \%$ of postgraduate students and $35 \%$ clinicians were responded that there was not a significant change in profit after the DPCO 2013 implementation while $41.67 \%$ interns were unaware of DPCO 2013 order itself.(Figure 5)

Figure 5: Opinion of Stakeholders Regarding Effect on Pharmacist's Profit

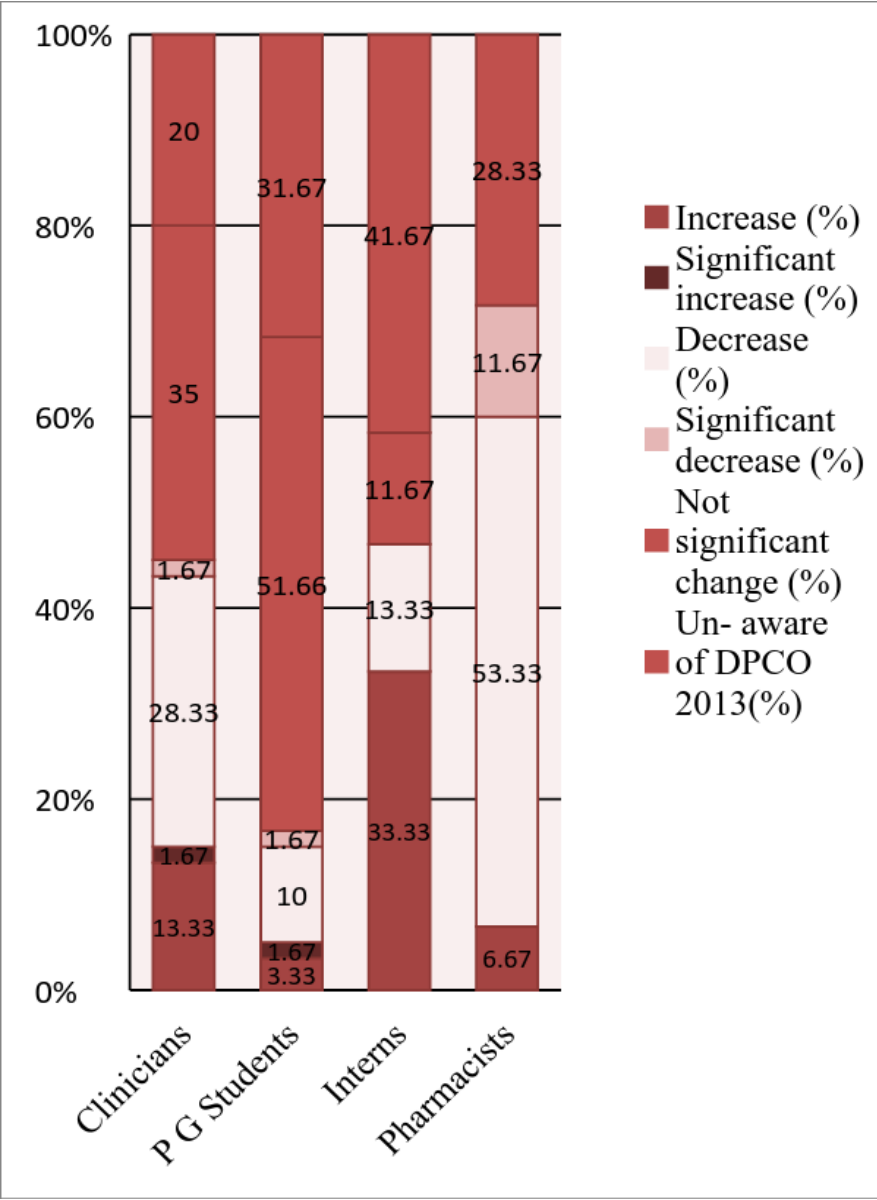

\section{Part B}

In the survey of actual economic impact, out of 348 essential medicines, MRPs of 287 drugs were available in CIMS India hand-book. These drugs were considered in the analysis. MRPs of 61 drugs were not quoted in CIMS India hand-book. Out of them, prices of $250(87.10 \%)$ essential medicines whose price were reduced in Q5 (quarter Oct -Dec 2013) compared with Q1 (quarter Oct- Dec 2012).

Prices of 36 (12.54\%) essential medicines were increased in Q5 compared with Q1 while only 1 drug silver sulfadiazine $(0.35 \%)$ whose price was not changed at all. This study revealed that, out of 


\section{JMSCR Vol||05||Issue||02||Page 18002-18012||February}

250 essential medicines, maximum number of essential medicines i.e.164 were showing $0>$ to $24 \%$ reduction in drug prices in quarter Oct - Dec 2013 while only 2 essential medicines were showing $75-100 \%$ price reduction. And rest of them were intermediate. [Table no. 1]

Table No. 1- Number of Drugs showing Percentage Reduction in MRPs in Quarter Oct - Dec 2013 (When compared with Quarter Oct - Dec 2012)

\begin{tabular}{|l|c|}
\hline Number of drugs & Percentage reduction \\
\hline 2 & $\mathbf{7 5 - 1 0 0 \%}$ \\
\hline 16 & $\mathbf{5 0 - 7 4 \%}$ \\
\hline 68 & $\mathbf{2 5 - 4 9 \%}$ \\
\hline 164 & $\mathbf{0 > - 2 4 \%}$ \\
\hline $\mathbf{2 5 0}$ & Total \\
\hline
\end{tabular}

It was observed that maximum number of essential medicines under price control were antimicrobial agents (60) followed by cardiovascular drugs (28), drugs acting on central nervous system (26) in last quarter of the study when compared with quarter Oct - Dec 2012 . (Table no.2)

Table No 2: Number of Drugs showing PRICE REDUCTION in Quarter Oct- Dec 2013 (Quarter 5)

[When compared with Quarter Oct- Dec 2012 (Quarter 1)]

\begin{tabular}{|l|l|l|l|}
\hline $\begin{array}{l}\text { No. of } \\
\text { drugs }\end{array}$ & $\begin{array}{l}\text { Drugs acting on organ } \\
\text { system }\end{array}$ & $\begin{array}{l}\text { No. of } \\
\text { drugs }\end{array}$ & $\begin{array}{l}\text { Drugs acting on organ } \\
\text { system }\end{array}$ \\
\hline 28 & Cardio-vascular system & 60 & $\begin{array}{l}\text { Infections and } \\
\text { infestations }\end{array}$ \\
\hline 23 & $\begin{array}{l}\text { Blood and blood forming } \\
\text { organ }\end{array}$ & 26 & $\begin{array}{l}\text { Central } \\
\text { system }\end{array}$ \\
\hline 15 & Gastro Intestinal tract & 18 & Malignancy \\
\hline 11 & Skin & 13 & Genitourinary system \\
\hline 10 & Respiratory system & 10 & Vitamins and minerals \\
\hline 5 & Endocrine system & 10 & Vaccines \\
\hline 4 & Immune disease & 6 & Sensory organs \\
\hline 4 & Others & 4 & $\begin{array}{l}\text { Musculoskeletal } \\
\text { system }\end{array}$ \\
\hline 250 & Total & 3 & Anti-diabetic agents \\
\hline
\end{tabular}

It was found that maximum reduction in drug prices in quarter Oct - Dec 2013 (when compared with quarter Oct - Dec 2012) was seen in chlorambucil (83.06\%) followed by vitamin A $(79.33 \%)$. [Table no. 3]
Table no. 3: 1st 5 Essential Medicines showing Highest Percentage Reduction in Prices in Quarter Oct - Dec 2013 (Q5) [When compared with Quarter Oct - Dec 2012 (Q1)]

\begin{tabular}{|l|c|c|c|c|}
\hline $\begin{array}{l}\text { P Percentage } \\
\text { reduction in } \\
\text { Q5 }\end{array}$ & $\begin{array}{c}\text { Cost per } \\
\text { unit } \\
\text { (Q5) } \\
\text { INR }\end{array}$ & $\begin{array}{c}\text { Cost per } \\
\text { unit } \\
\text { (Q1) } \\
\text { INR }\end{array}$ & $\begin{array}{c}\text { Strength \& } \\
\text { package }\end{array}$ & Drug \\
\hline $\mathbf{- 8 3 . 0 6}$ & 2.59 & 15.30 & $\begin{array}{c}2 \mathrm{mg}, \\
25 \mathrm{Tablets}\end{array}$ & Chlorambucil \\
\hline $\mathbf{- 7 9 . 3 3}$ & 0.27 & 1.33 & $\begin{array}{c}50000 \mathrm{IU}, 10 \\
\text { Capsules }\end{array}$ & Vitamin A \\
\hline $\mathbf{- 6 9 . 7 3}$ & 0.03 & 0.09 & $\begin{array}{c}20 \mathrm{mg}, \\
14 \mathrm{Tablets}\end{array}$ & Famotidine \\
\hline $\mathbf{- 6 8 . 4 2}$ & 0.17 & 0.52 & $\begin{array}{c}0.5 \%, \\
20 \mathrm{ml} \text { vial }\end{array}$ & \begin{tabular}{c} 
Bupivacaine \\
\hline $\mathbf{- 6 6 . 3 3}$
\end{tabular} \\
& 1.32 & 3.92 & $\begin{array}{c}50 \mathrm{mg} \\
(500 \mathrm{mg}+ \\
25 \mathrm{mg})\end{array}$ & $\begin{array}{c}\text { Artesunate } \\
\text { Sulfadoxine }+ \\
\text { Pyrimethamin } \\
\mathbf{e}\end{array}$ \\
\hline
\end{tabular}

It was found that maximum increment in drug prices in quarter Oct - Dec 2013 (when compared with quarter Oct - Dec 2012) was seen in mesna $(94.40 \%)$ followed by betamethasone injection $(59.89 \%)$. [Table no. 4]

Table no. 4: 1 st 5 Essential Medicines showing Highest Percentage Increment in Prices in Quarter Oct - Dec 2013 (Q 5) [When compared with Quarter Oct - Dec 2012 (Q1)]

\begin{tabular}{|c|c|c|c|c|}
\hline $\begin{array}{l}\text { Percentage } \\
\text { increment in } \\
\text { Q5 }\end{array}$ & $\begin{array}{l}\text { Cost } \\
\text { per } \\
\text { unit } \\
\text { (Q5) } \\
\text { INR }\end{array}$ & $\begin{array}{l}\text { Cost } \\
\text { per } \\
\text { unit } \\
\text { (Q1) } \\
\text { INR }\end{array}$ & $\begin{array}{l}\text { Strength \& } \\
\text { package }\end{array}$ & Drug \\
\hline 94.40 & 0.35 & 0.177 & $\begin{array}{l}200 \mathrm{mg} \text { in } 2 \mathrm{ml} \\
\text { Ampoule }\end{array}$ & Mesna \\
\hline 59.89 & 6.33 & 3.961 & $\begin{array}{l}4 \mathrm{mg} \text { in } 1 \mathrm{ml} \\
\text { Ampoule }\end{array}$ & $\begin{array}{l}\text { Betamethasone } \\
\text { injection }\end{array}$ \\
\hline 41.34 & 14.91 & 10.552 & $\begin{array}{l}\text { 40IU/ml, } 10 \mathrm{ml} \\
\text { Ampoule }\end{array}$ & Insulin soluble \\
\hline 30.81 & 28.13 & 21.5 & $\begin{array}{l}2 \mathrm{mg} / \mathrm{ml}, 2 \mathrm{ml} \\
\text { Ampoule }\end{array}$ & Vecuronium \\
\hline 31.62 & 71.6 & 54.4 & $\begin{array}{l}0.125 \mathrm{mg} \\
10 \text { Tablets }\end{array}$ & $\begin{array}{l}\text { Methyl- } \\
\text { ergometrine }\end{array}$ \\
\hline
\end{tabular}

[INR = Indian National Rupees $]$-Table 3 and 4

\section{DISCUSSION}

The Drug Price Control Order, 2013 was in effect from June 2013 end, was an implementation by the National Pharmaceutical Pricing Authority (NPPA) to revise the price of 652 formulations listed under NLEM 2011 make them affordable for common man with respect to DPCO $2013^{[8]}$.

In views of perceived impact, it was studied 
awareness of DPCO 2013 in various stakeholders like Clinician, Post-graduate students, Interns, Pharmacists and Patients. It was observed that awareness of DPCO 2013 was highest amongst pharmacists $(100 \%)$ followed by clinicians $(80 \%)$, Post-graduate students (68.33), Interns (58.33\%) and least in patients (21.66\%) (Figure1). It was highest amongst pharmacist i.e. 100\% and least in patients $(21.66 \%)$. Still in interns and post-graduate students, knowledge of DPCO was lacking i.e. $58.33 \%$ and $68.33 \%$ respectively. Information of DPCO 2013 implementation and updates should be given to post-graduate students and interns via seminars, lectures so that it will encourage in prescribing affordable medicines to the patients.

According to feedback received from respondents, newspaper was found to be most common source of information regarding DPCO 2013 (Figure 2). This was signifying that DPCO 2013 was burning topic for newspapers for the year of $2013-2015^{[14]}$.

It was observed that, $83 \%$ pharmacists, $74 \%$ clinicians, $58 \%$ post-graduate students, $41 \%$ interns and $22 \%$ patients responded that maximum beneficiary agent is patient after implementation of Drug Price Control Order 2013 (Figure 3).

Regarding availability of essential medicines after DPCO 2013 implementation, 88.33\% of pharmacist replied that some of medicines were out of stock. (Figure 4) In this study, pharmacists revealed that drugs like azithromycin, amoxicillin - clavulanic acid, metoprolol, amlodipine, cefixime, propranolol, ciprofloxacin, enalapril were out of stock after DPCO 2013 implementation. Likewise, Rathore et al in his article named 'Impact of DPCO 2013 on availability of essential medicines in market' pointed out that there was drug shortage in various cities of India and patients were facing a shortage of drugs like crucial antibiotics, anxiolytics, betablockers, multi-vitamins and other medicines ${ }^{[7]}$. Report in Times of India ${ }^{[15]}$ revealed the same problem of shortage of drugs like Augmentin 625, antacids, multivitamin, beta blockers which are used extensively to treat indoor patients. The same reaction of pharmacists was noted in feedback assessment. $45 \%$ of post-graduate students and
$41.67 \%$ of clinicians replied that there could be increase availability of essential medicines (Figure 4) indicating that responses received from them and pharmacists were quite opposite but feedback from pharmacists is obvious as they are directly involved in dispensing medicines. Major portion i.e. $76.67 \%$ patients were unaware of DPCO 2013 is clearly suggesting that a significant component of Indian society is even unaware of the Government's major lead to cut prices of drugs as well burden on health spending.

Regarding the profit, $53.33 \%$ of pharmacists answered that there was a decrease in profit of pharmacists after implementation of DPCO 2013 (Figure 5). Rathore et al (2013) ${ }^{[7]}$ in an article named 'Impact of DPCO 2013 on the availability of essential medicines in market' noted that patients were facing shortage of drugs which are used on a regular basis for treatment of indoor patients. Due to this fact, pharmacists had to look for the substitutes and sales of the most commonly used drugs were declined as compared to sales before DPCO 2013 implementation. The response of pharmacists regarding their profit is going in line with Rathore et al article.

In survey of economic impact, only those essential medicines whose prices were quoted in CIMS India hand-book for last quarter i.e. Oct - Dec 2012 and each quarter of year 2013 were considered only. Prices of 287 essential medicines were quoted in CIMS India printed hand-book and prices of 61 drugs like activated charcoal, barium sulphate, methyl cellulose, methylene blue, dextran 40 and 70, coal tar, oxygen, nitrous oxide etc. were not mentioned in CIMS India hand-book for the same period. NPPA also could not fix ceiling prices of 98 formulations out of 652 due to non-availability of data/ information in retail channel ${ }^{[16]}$.

Out of them, prices of 250 essential medicines in quarter Oct - Dec 2013 (as compared to quarter Oct - Dec 2012) were reduced i.e. $87.10 \%$ of essential medicines were under price control in this study and 36 drugs (12.54\%) were showing increment in drug prices (Table no1). Some of studies are available in India comparing the cost of the same drug sold 
under different brand names by different pharmaceutical companies where difference in the maximum and minimum price of the same drug formulation manufactured by different pharmaceutical companies and percentage variation in price was calculated ${ }^{[10]}$. But there is no similar study available to quantify inter- quarter comparisons (before and after DPCO 2013 implementation) to calculate percentage changes in drug costs.

Report of Indian Express ${ }^{[17]}$ dated Jan 21, 2015 noted that prices of all formulation covered under the National Pharmaceutical Pricing Authority's drug price control order 2013 have dropped i.e. $100 \%$ reduction in drug prices were seen for essential medicines which was more than this study. Because percentage reduction calculation was based on average MRP of drug in this study, while in report of Indian express, percentage reduction was calculated with respect to maximum MRP of drug available in market before and after DPCO 2013 implementation.

The most of drugs under price control in this study were antimicrobial agents followed by cardiovascular drugs in final quarter of the study (Table no.2). The spending on the treatment of infections and cardiovascular disorders like hypertension, prophylactic treatment of myocardial infarction and congestive heart failure would be significantly reduced. Poor sanitation leading to various infections, hypertension, and myocardial infarction are the most prevalent diseases in developing countries like India ${ }^{[18]}$, by reducing expenditure on treatment of these diseases certainly curtail the burden of spending on health- care for common man.

Some of the pharma companies have suffered a decrease in the ceiling prices of drugs after the DPCO notification however others have benefited by increased in ceiling prices of drugs after the new $\mathrm{DPCO}^{[9]}$. As a result, along with significant price capping, MRPs of some brands were raised. Hence in present study, $12.54 \%$ drugs were showing increment on MRPs in last quarter of the study.

Daily News and Analysis (DNA) [Report on 3rd March 2015] [19] mentioned that out of 509 formulations of essential medicines, above $40 \%$ price reduction was occurred in the case of 127 essential medicines, while prices of 34 drugs were declined in the range of $35-40 \%$. In this study, it was found that average MRP of 232 drugs for quarter 5 (Oct - Dec 2013) when compared to quarter 1 (Oct- Dec 2012) were dropped up-to $49 \%$ and 16 were declined by $50-74 \%$ and remaining 2 were reduced by more than $75 \%$ (Table no. 1). Reason for the variation of results from DNA report and this study is that report of DNA was revealed in 2015 while study results were based on average MRPs in financial year 2013.

It was found that amongst 287 drugs, maximum percentage reduction was observed for chlorambucil i.e. $83.06 \%$ followed by vitamin A $(79.33 \%$ ) (Table no.3). Chlorambucil is drug of choice for long term maintenance therapy of chronic myeloid leukaemia and non - Hodgkin lymphoma ${ }^{[20]}$. Hence the cost of therapy of chronic myeloid leukaemia and non Hodgkin lymphoma would be definitely decreased due to price control of chlorambucil. As a result, economic burden on patients as well as hospital especially, Government set up, would be reduced. Another drug showing significant percentage reduction on MRP was Vitamin A (Table no.3) which is most commonly used by National Blindness Programmes. The price reduction of vitamin A would be beneficial for National Blindness Programmes, it would help to curtail budget of national blindness programme. Therefore it is win-win situation for service provider (Government) as well as end user (Patients).

Very few studies have done to study impact of DPCO 2013 on pharma sector as well as Indian society so not as much of data was available for comparison of study results. Most of study results were compared with available news reports published in various news reports. While analysing economic impact, the present study was restricted to financial year 2013 to measure price reduction of essential medicines, yet in year of $2014-2015$, along with NLEM update in year 2015 by core committee constituted by Ministry of Health and Family Welfare ${ }^{[21]}$, NPPA had made an endeavour to embrace non-essential medicines under price 
control $[17,22,23,24]$ and regularly notified ceiling prices essential medicines. These non-essential medicines as well as newly added essential medicines should be considered also in order to analyse actual economic impact on pharma sector after DPCO 2013 implementation. There are numerous ways and factors to study its influence on essential medicines in India. However, it would be huge with unrestricted scope.

\section{CONCLUSION}

With the objective to improvise and endow with the basic health care and availability of basic medicines at an affordable price across the country, DPCO 2013 order empowers the NPPA to regulate prices of 348 essential drugs. The price reduction was noticed significantly in majority of anticancer, vitamins, antibacterial, cardiovascular drugs to make them affordable for the common man. Although DPCO 2013 has been introduced as a novel decision, it has also led to the shortages of essential medicines like azithromycin, amoxicillin clavulanic acid, metoprolol, amlodipine, cefixime, ciprofloxacin, enalapril causing major concern to the patients. In order to overcome this problem of shortage, the government should take strict action to continue the manufacturing of drugs by the manufacturers as well as to avoid artificial storage of drugs whose prices are reduced by manufacturers.

Moreover information of DPCO 2013 was found to be lacking amongst post-graduate students and interns compared to pharmacists. Hence knowledge of DPCO 2013 implementation and updates should be improvised in medical personnel.

This study has vast scope to measure price variation beyond last quarter of this study. Thus, such studies should be ongoing because the impact is dynamic which requires continuous monitoring and feedback with arrival of new information and updates.

ACKNOWLEDGEMENT: NIL

SOURCE OF SUPPORT - Nil

CONFLICT OF INTEREST: The authors declare that they have no conflict of interest.

\section{REFERENCES}

1. Kumar PS, Balmuralidhara V, Kumar TP, Dave AJ. Need for Drug Price Control in India. Advanced Journal of Pharmacie and Life science Research [Internet]. 2013 [Cited 2016 Mar 4]; 1(1):22-30. Available from: http://ajplronline.org/uploadfile/6352638362 99975198.pdf.

2. The Essential Commodities Act. Parliament; India [Internet]. 1955 Apr. [Cited 2014 Nov 1]; Available from: http://nfs.delhi.gov.in/ForDownload/Essenti alAct1955.pdf

3. The Decontrol of Drug Prices in India [Internet]. Implications for the Indian Pharma Industry. Internet. [Cited 2014 Dec 24] Available from http://ccs.in/internship_papers/2002/27.pdf

4. The Drugs (Prices Control) Order, 2013 [Internet]. National Pharmaceutical Pricing Authority; Ministry of Chemicals and Fertilizers; Govt. of India. 2013 May 15 [Cited 2014 Dec 05]; Available from http://www.nppaindia.nic.in/DPCO2013.pdf.

5. The Drugs (Prices Control) Order, 1995 [Internet]. National Pharmaceutical Pricing Authority; Ministry of Chemicals and Fertilizers; Govt. of India. 1995 Jan 6. [Cited 2014 Dec 05]; Available from http://www.nppaindia.nic.in/DPCO1995.pdf.

6. National Essential Drug List [Internet]. Delhi; Ministry of Health and Family Welfare; Government of India; 2011; 1-46 [Cited 2014 Dec 05]; Available from: http://cdsco.nic.in/National\%20List\%20of\% 20Essential\%20Medicine\%20final\%20copy.pdf.

7. Rathore A, Mantry P. Impact of DPCO 2013 on availability of essential medicines in market. International Journal of Economics, Commerce and Management [Internet].2013 [Cited 2015 Dec 12]; 1(1):1-3. Available from: http://ijecm.co.uk/wp-content/ uploads/ 2014/ 01/ 117.pdf.

8. Kumar V, Gupta NV, Kumar KA. A 
comparison between old and latest systems in DPCO. International Journal of Pharmacy and Pharmaceutical Sciences [Internet].2014 [Cited 2016 Mar 15]; 6(2):19-20. Available from:

http://www.researchgate.net/publication/263 657518_A_comparision_between_old_and_1 atest_systems_in_DPCO.

9. Shinde NG. Drug Price Control Order and its Impact on Pharma Sector. Short Communication [Internet]. [Cited 2015 May 31]; Available at: https://www.academia.edu/6874122/Drug_P rice_Control_Order_and_its_Impact_on_Pha rma_Sector.

10. Chawan VS, Gawand KV, Badwane SV. Cost analysis of oral hypolipidemic agents available in India. International Journal of Basic \& Clinical Pharmacology [Internet]. 2014 Dec [Cited 2016 Jul 29]; 3(6):954-957. Available

from: http://www.scopemed.org/fulltextpdf.php?m no $=1448$

11. ICH Harmonised Tripartite Guideline \& Statistical Principles For Clinical Trials. International Conference On Harmonisation Of Technical Requirements For Registration Of Pharmaceuticals For Human Use: European union; 1998: 20- 21. [Accessed as on 25 Dec 2015] Available at:

http://www.ich.org/fileadmin/Public_Web_S ite/ICH_Products/Guidelines/Efficacy/E9/St ep4/E9_Guideline.pdf.

12. Promoting rational use of medicines: core components. WHO policy on perspectives on medicines : Geneva, World Health Organisation ; Sept 2002; $1-6$.

13. UBM Medica India Private Limited. CIMS Updated Prescriber's Hand-book; 2013.

14. Baby S. Drug price control order, 2013Analysis. [Internet] The Hindu, 2013; 1-19. [Cited 2015 May 31]; Available at: https:// www.academia. edu/4982248/ DPCO_2013_ANALYSIS.

15. Unnithan C, Sharma R. DPCO driving crucial drugs off shelves, say doctors [Internet]. The Times of India. 2013 Sept 11[Cited 2015 Aug 12]; Available from: http://timesofindia.indiatimes.com/city/ahme dabad/DPCO-drivingcrucial-drugs-offshelves-say-doctors/articleshow/224 74706.cms.

16. National Pharmaceuticals Pricing Policy. (NPPA) [Internet]; Ministry of Chemicals and Fertilizers; Govt. of India. 2015; [Cited 2015 Nov 27]; Available from: http://www.nppaindia.nic.in/order/list98med icines-2015.pdf

17. Sasi A. 1 in 4 drugs on NPPA price cap list crash by over $40 \%$ Price control issue may come up for discussion during US President's visit [Internet]. The Indian Express. 201521 Jan [Cited on 2015 Aug 12]; Available from: http://indianexpress.com/article/business/bus iness-others/1-in-4-drugs-on-nppa-price-caplist-crash-by-over-40/.

18. Patel V, Chatterji S, Chisholm D, Ebrahim S, Gopalakrishna G, Mathers C, et al. India: Towards Universal Health Coverage 3: Chronic diseases and injuries in India. Lancet [Internet].2011 Jan [Cited 2015 Jul 29]; 377:413 - 428. Available from: http://www.who.int/choice/publications/Chr onic_diseaseIndia.pdf

19. Prices of 509 essential drugs reduced: Govt [Internet]. DNA. 2015 Mar 3. [Cited 2015 Aug 10]; Available from: http://www.dnaindia.com/money/reportprices-of-509-essential-drugs-reduced-govt2065842.

20. Tripathi KD. Essentials of Medical Pharmacology. 7th edition. New Delhi, India: Jaypee brother's medical publishers (p) 1td; 2013.Chapter 1, Chemotherapy of neoplastic diseases; $p$ 857-877.

21. National Essential Drug List [Internet]. Delhi; Ministry of Health and Family Welfare; Government of India; 2015; 1-117 [Cited 2016 Dec 05]; Available from: 
http://cdsco.nic.in/WriteReadData/NLEM-

2015/NLEM,\%202015.pdf

22. Mukharjee R. Major diabetes, cardiac drugs to become up to $35 \%$ cheaper [Internet]. Times of India (India). 2014 Jul 14 [Cited 2015 Jan 13]; Available from: http://timesofindia.indiatimes.com/india/maj or-diabetes-cardiac-drugs-to-become-up-to35-cheaper/

23. National Pharmaceuticals Pricing Policy. (NPPA) [Internet]; Ministry of Chemicals and Fertilizers; Govt. of India. 2014; [Cited 2015 Nov 6]; Available from: http://www.nppaindia.nic.in/prnotif2014/prnot-retail-para5-2014.html

24. National Pharmaceuticals Pricing Policy. (NPPA) [Internet]; Ministry of Chemicals and Fertilizers; Govt. of India.2015; [Cited 2015 Nov 6]; Available from: http://www.nppaindia.nic.in/wh-new2015/wh-new-30-2015.html 